\title{
Effect of Section Size as a Measure of Cooling Rate on the Solidified Microstructure and Mechanical Properties of Sand-Cast Al-Si Eutectic Alloy
}

\author{
Udochukwu Mark
}

Department of Materials and Metallurgical Engineering

Federal University of Technology, PMB 1526 Owerri, Imo State - Nigeria

udochukwu.mark@futo.edu.ng

\begin{abstract}
Keywords: Section size, cooling rate, Chvorinov's rule, eutectic alloy, microstructure, mechanical properties.
\end{abstract}

\begin{abstract}
Several factors contribute to the development of structure and properties of aluminium alloy castings. This study investigated the singular effect of cooling rate on the as-cast structure and mechanical properties of an aluminum-silicon eutectic alloy, keeping other factors such as pouring temperature, melt treatments, physical and thermal properties of the mould, and alloy composition constant. The rate of cooling was varied by employing different casting section sizes, based on the variation of rate of heat extraction given by solidification time as predicted by the Chvorinov's rule. Four test bars of section sizes 10,20,30, and $40 \mathrm{~mm}$ respectively were cast in sand mould using the same gating system. Spectrometric analysis of the alloy formulated revealed that it could be specified approximately as Al-12.8Si-1.0Cu alloy. The study showed that as section size decreased from $40 \mathrm{~mm}$ to $10 \mathrm{~mm}$; the solidification time reduced (i.e. the cooling rate increased), the microstructure got finer, the silicon flakes became more uniformly distributed, and the mechanical properties generally improved. The tensile strength, ductility, and hardness all increased in the order of decreasing section size, i.e. increasing cooling rate. The mechanical properties were found to be linearly correlated with section size or cooling rate. Whereas the elongations were lower than values for pure aluminium, the strength and hardness were significantly higher than values for the pure metal. It is concluded that the cooling rate modifies the microstructure and improves the mechanical properties of as-cast Al-Si eutectic alloys
\end{abstract}

\section{Introduction}

The fabrication and use of metallic materials depend mostly on such mechanical properties as strength, hardness, and ductility. The mechanical properties of cast alloys that are not heat-treatable develop during solidification and are dependent on the solidification conditions [1]. Silicon (density $=2.33 \mathrm{~g} / \mathrm{cm}^{3}$ ) is one of the few elements that can be added to aluminium (density $=2.7 \mathrm{~g} / \mathrm{cm}^{3}$ ) without essentially changing the density of the latter. However, the hardness and tensile strength of aluminium are considerably increased by the addition of silicon although, naturally, these improvements are accompanied by a loss in ductility [1]. Silicon is present in most commercial aluminium casting alloys. As an alloying element, it is used in various amounts up to 14 percent $\mathrm{Si}$ in hypo-eutectic and eutectic alloys. Alloys of hypereutectic composition can contain as much as $15-25 \% \mathrm{Si}$ [1]. The solubility of $\mathrm{Si}$ in $\mathrm{Al}$, the $\alpha$-phase, is limited to 1.65 percent at the eutectic temperature $\left(577^{\circ} \mathrm{C}\right.$ or $1072^{\circ} \mathrm{F}$ ) and less than 0.05 percent at room temperature. Un-dissolved silicon constitutes the $\beta$-phase, i.e. silicon particles containing an extremely small percentage of aluminium [1] [2]. Al-Si is a simple eutectic system with two solid solution phases, face-centred cubic (Al) and diamond cubic ( $\mathrm{Si}$ ) as shown in Figure 1. The eutectic composition has been a matter of debate, but it is now generally accepted as $12.6 \mathrm{wt} \% \mathrm{Si}$. The eutectic temperature in all cases is $577^{\circ} \mathrm{C}$ [1] [2] [3] [4].

Binary aluminium-silicon alloys belong to those alloy systems in which a non-metallic phase, which is present besides a metallic phase in the microstructure, determines the overall properties of the alloy largely. Among the most interesting and most important binary alloys in the Al-Si system are those of eutectic or near-eutectic compositions because of their excellent pourability (fluidity). 
Moreover, they are gas and fluid impermeable (pressure-tightness) and can be welded autogenously. Due to the formation of a protecting layer on the surface, they also exhibit good corrosion resistance. The mechanical properties of these alloys are notably sensitive to the size, shape and distribution of the silicon particles present in the microstructure, which in turn, may be manipulated by choosing appropriate solidification conditions or adding suitable additions as structure modifiers [1] [5].

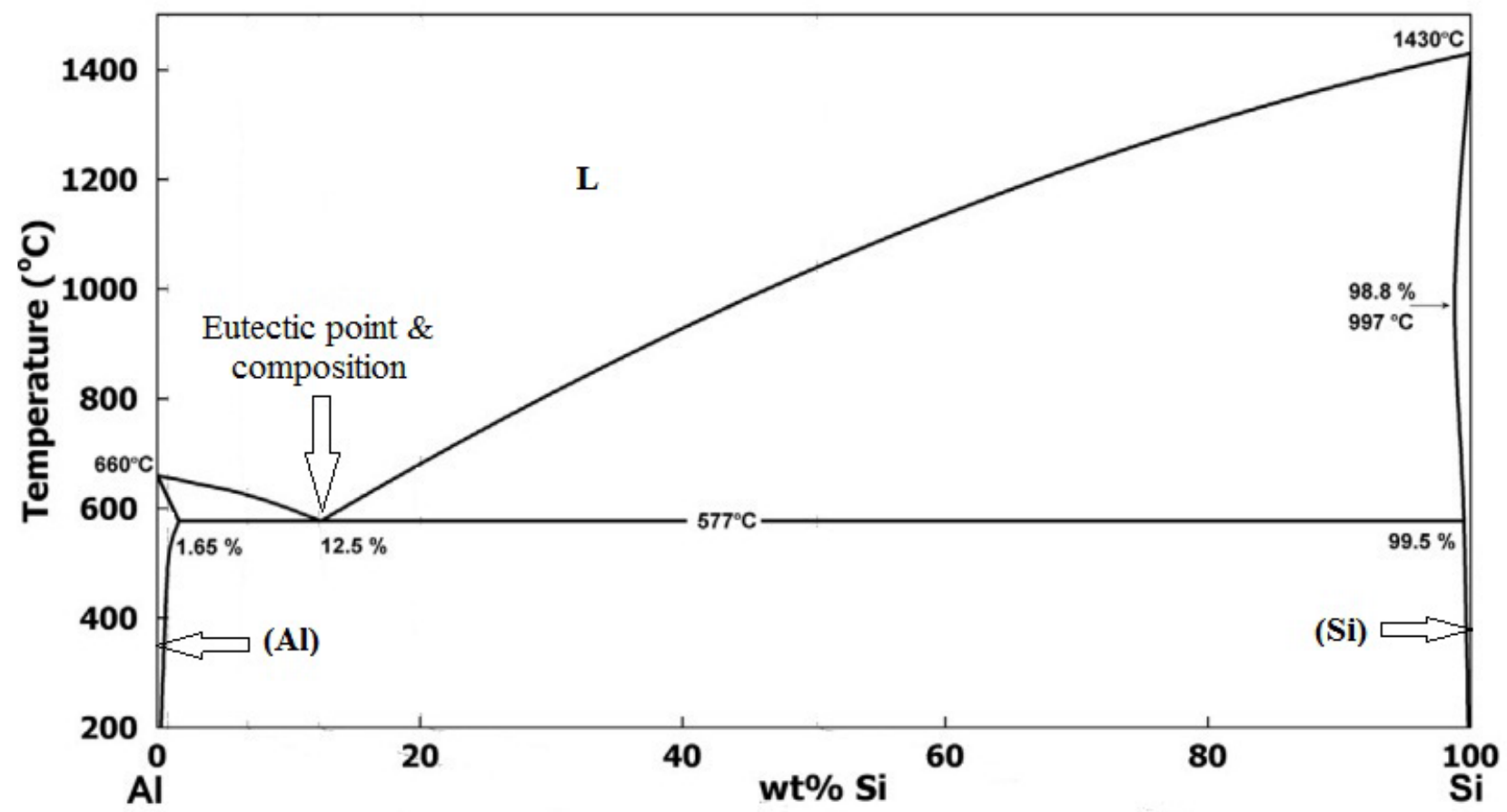

Figure 1: Al-Si Binary Phase Diagram Showing the Eutectic Point and Composition [1] [4]

Al-Si alloys (i.e. aluminium casting alloys) occupy significant position in modern industry and manufacturing technology [5]. Small-scale foundries in Aba, Nnewi and elsewhere in the country make most of their spare parts (especially motorcycle parts) using aluminium-silicon alloys [6] [7]. Aluminium is one of the most versatile of the common foundry metals. Apart from lightweight, the special advantages of aluminium alloys for castings are the relatively low melting temperatures, negligible solubility for all gases except hydrogen, and the good surface finish that is usually achieved with final products.

The most widely used Al-Si eutectic alloys are those containing between 9 and $13 \%$ silicon, with occasionally less than $1 \%$ copper. These alloys are of approximately eutectic composition, a fact that makes them eminently suitable as die-casting alloys, since their freezing range will be small. They are also used in the form of general-purpose sand castings and die-castings and can be used in the "as-cast" condition, i.e. no heat-treatment is required - with such applications as car sumps, gearboxes and radiators and a wide variety of thin-walled and complex castings [3] [5]. The Al-Si eutectic alloys are also lighter than the Al-Cu alloys and are widely used for automobile castings, including water-cooled manifolds and jackets, motor housing, etc. and for pump parts in the chemical and dye industries and for many domestic castings [5] [8] [9].

\subsection{Solidification and Structure of Eutectic Alloys}

As with all solidification processes, the eutectic solidification reaction occurs by a nucleation and growth phenomenon [2] [10] [11]. It has been observed that the nucleation event commences at a temperature below the eutectic temperature [i.e. there is some under-cooling or super-cooling] with the heterogeneous nucleation of one of the eutectic phases on nucleants present in the liquid and is completed by the heterogeneous nucleation of the second eutectic phase on the first [2] [11]. Both the rate of nucleation and the rate of growth increase with increasing under-cooling. Many authors agree that the rate of nucleation increases with under-cooling (as in thin sections in castings) leading to fine structures and better mechanical properties. Conversely, the cooling rate of a casting may be reduced 
by increasing the section size and this leads to a decrease in the eutectic cell number, resulting to poor mechanical properties [1] [2].

\subsection{Modification in Al-Si Alloys}

Although Si improves the castability of Al, it also impairs mechanical properties to an extent that depends on the size, shape and distribution of the Si particles [1] [2[ [12]. But, slow solidification of a pure Al-Si alloy produces a very coarse microstructure in which the eutectic comprises large plates or needles of $\mathrm{Si}$ in a continuous Al matrix [1]. The eutectic itself is composed of individual cells within which the Si particles appears to be interconnected. Alloys having coarse eutectic exhibit low ductility because of the brittle nature of the large plates [2] [12]. However, rapid cooling (chilling), as occurs during permanent mould casting (e.g. die-casting), greatly refines the microstructure. This means that the Si phase assumes a fibrous form with the result that both ductility and tensile strength are much improved [2] [13] [14] [15]. Using thin sections in sand casting may also induce rapid cooling and consequent refinement of microstructure [16] [17].

Structural modification is achieved either by rapid solidification during casting or by adding modifying agents, usually sodium or strontium. Small additions of phosphorus have been reported to refine rather than modify the microstructure [2]. Unmodified structures, commonly called acicular, are composed of platelet-like particles of silicon, which form brittle planes of weakness. In a wellmodified structure, often called fibrous, the silicon particles are prevented from growing. Instead, they retain the shape of very small spheroids, contributing to higher elongations (ductility) [9] [12].

\section{Materials and Methods}

The materials used for pattern-making, mould-making, and alloy preparation include gmelina wood; aluminium ingot of $98 \%$ purity sourced from Projects Development Institute (PRODA), Enugu; silicon granules of $99 \%$ purity sourced from First Aluminium (Nig.) Plc, Port-Harcourt; natural foundry moulding sand, aluminium chloride $\left(\mathrm{AlCl}_{3}\right)$ granules; plumbago (graphite powder) and talc as parting agents. The wood was turned on a woodwork lathe to produce cylindrical patterns for the test bars. The conical frustum which served as pattern for the riser was also made from wood. The mould cavity and its gating system were made by means of hand moulding tools such as mould boxes, spade, trowel, riddles, rammers, bellows, heart \& square, vent wire, and head-pan. Digital weighing balance was used to weigh the charge of aluminium and silicon required. Melting was achieved using a laboratory size tungsten-arc electric furnace while a steel pot served as the crucible. The composition of the alloy was ddetermined by means of a spectrometer available at First Aluminium (Nig.) Plc, Port-Harcourt. Metallographic equipment and microscope were used for microstructural examination. Specimens for tensile and hardness tests were obtained and prepared by means of a hacksaw and center lathe. Tensile testing was done using Monsanto tensiometer, while hardness was determined using Brinell hardness testing machine available at Engineering Lab., Standards Organization of Nigeria (SON), Enugu.

\subsection{Design Calculations}

Four cylindrical test bars were designed to have the same length but different diameters or section thicknesses. This is in accordance with the Chvorinov's rule, which predicts that such bars will undergo different cooling rates according to equation 1 [18].

$$
t_{s}=B \cdot\left(\frac{V}{A}\right)^{n}
$$

In equation $1, t_{S}$ is the total solidification time required for the casting to solidify, $\mathrm{V}$ is the casting volume, $A$ is the surface area of the casting, $B$ is the mould constant, and $n$ have values ranging from 1.5 to 2.0 and is constant for a given combination of metal and mould. Given that both $B$ and $n$ are constants, the only variable affecting solidification time $\left(t_{s}\right)$ and hence cooling rate is the casting modulus, $V / A$. The average cooling rate $\left(R_{c}\right)$ should be equal to the pouring temperature $\left(T_{p}\right)$ of the melt minus room temperature $\left(T_{r}\right)$ divided by total solidification time $\left(t_{s}\right)$. Since the test bars are cast 
from the same melt, $\left(T_{p}-T_{r}\right)$ will be constant for all the test bars and only $t_{s}$ will vary. Thus, low $t_{s}$ would imply rapid cooling rate $\left(R_{c}\right)$.

The bars were designed to have section sizes of 10, 20, 30 and $40 \mathrm{~mm}$ respectively; each of length $200 \mathrm{~mm}$. Patterns for the test bars were machined from gmelina wood on the woodwork lathe. The solidification shrinkage allowance for Al-Si alloys of eutectic or near-eutectic composition is $\frac{5}{32}$ in/ft or $\frac{13}{100} \mathrm{~mm} / \mathrm{cm}$, i.e. $0.13 \mathrm{~mm} / \mathrm{cm}$ [3] [18]. This means that a solidified cast bar of $10 \mathrm{~mm}$ dimension will require a pattern dimension of $10.13 \mathrm{~mm}$. The dimensions of patterns for the four test bars are as shown in Table 1.

Table 1: Dimensions of patterns with contraction or shrinkage allowance*

\begin{tabular}{|l|c|c|c|c|}
\hline \multirow{2}{*}{$\begin{array}{c}\text { Designation and Shape of Cast } \\
\text { Test Bars and Riser }\end{array}$} & \multicolumn{2}{|c|}{ Pattern } & \multicolumn{2}{c|}{ Test Bar } \\
\cline { 2 - 5 } & $\begin{array}{c}\text { Diameter } \\
(\mathrm{mm})\end{array}$ & $\begin{array}{c}\text { Length } \\
(\mathrm{mm})\end{array}$ & $\begin{array}{c}\text { Diameter } \\
(\mathrm{mm})\end{array}$ & $\begin{array}{c}\text { Length } \\
(\mathrm{mm})\end{array}$ \\
\hline A (cylinder) & 10.13 & 202.6 & 10 & 200 \\
\hline B (cylinder) & 20.26 & 202.6 & 20 & 200 \\
\hline C (cylinder) & 30.39 & 202.6 & 30 & 200 \\
\hline D (cylinder) & 40.52 & 202.6 & 40 & 200 \\
\hline \multirow{2}{*}{ Riser (Conical Frustum) } & $\mathrm{D}=60.78$ & \multirow{2}{*}{101.3} & $\mathrm{D}=60$ & \multirow{2}{*}{100} \\
\cline { 2 - 4 } \cline { 5 - 5 } & $\mathrm{d}=50.65$ & $\mathrm{~d}=50$ & \\
\hline
\end{tabular}

* These will contract to the required sizes for test bars after solidification.

In terms of logarithm, equation 1 becomes equation $2 \mathrm{a}$.

$$
\log t_{s}=\log B+n \cdot \log \left(\frac{V}{A}\right)
$$

Since the four test bars would be cast in the same mould using the same alloy melt, the mould constant $B$ is uniform to the four test bars. consequently, $\log B$ is a constant, say $k$. The casting modulus $(V / A)$ has an exponent $n$ which is usually approximated to 2 and is constant for each alloy and mould combination. Therefore, equation $2 \mathrm{a}$ can be rewritten as equation $2 \mathrm{~b}$ :

$$
\log t_{s}=k+2 \log \left(\frac{V}{A}\right)
$$

As shown in Table 2, cooling rate is expected to increase as the casting modulus $(\mathrm{V} / A)$ decreases. Also, the ratio of thickness to length of test bar $(d / L)$ should fall with the ratio $(\mathrm{V} / A)$ implying faster cooling rate. Therefore, using the values of $V / A$ in Table $2, \log t_{s}$ for the four different test bars and riser would be:

$$
\begin{aligned}
& \log t_{s_{A}}=k+2 \log 2.47=k+0.785394 \\
& \log t_{s_{B}}=k+2 \log 4.88=k+1.376840 \\
& \log t_{s_{C}}=k+2 \log 7.23=k+1.718277 \\
& \log t_{S_{D}}=k+2 \log 9.52=k+1.957274 \\
& \log t_{s_{R}}=k+2 \log 12.12=k+2.146704
\end{aligned}
$$

Since $k$ has a constant value in equations $3-7$; the implication is that $k$ is related as shown in equation 8 .

$$
\begin{aligned}
k=\log t_{s_{A}}-0.785394=\log t_{s_{B}}- & 1.376840=\log t_{s_{C}}-1.718277 \\
& =\log t_{s_{D}}-1.957274=\log t_{s_{R}}-2.146704
\end{aligned}
$$

Therefore; equations 9-12 are derived from equation 8 .

$$
\begin{aligned}
& \log t_{s_{B}}-\log t_{s_{A}}=\log \left(\frac{t_{s_{B}}}{t_{s_{A}}}\right)=1.376840-0.785394=0.591446 \\
& \log t_{s_{C}}-\log t_{s_{A}}=\log \left(\frac{t_{s_{C}}}{t_{s_{A}}}\right)=1.718277-0.785394=0.932883
\end{aligned}
$$




$$
\begin{gathered}
\log t_{s_{D}}-\log t_{s_{A}}=\log \left(\frac{t_{s_{D}}}{t_{s_{A}}}\right)=1.957274-0.785394=1.17188 \\
\log t_{s_{R}}-\log t_{s_{A}}=\log \left(\frac{t_{s_{R}}}{t_{s_{A}}}\right)=2.146704-0.785394=1.36131
\end{gathered}
$$

Consequently; the relative solidification times using the solidification time for the thinnest bar (bar A) as basis are given by equations 13-17.

$$
\begin{aligned}
& t_{s_{A}} / t_{s_{A}}=10^{0}=1 \\
& t_{s_{B}} / t_{s_{A}}=10^{0.591446}=3.90 \approx 4 \\
& t_{s_{C}} / t_{s_{A}}=10^{0.932883}=8.57 \approx 9 \\
& t_{s_{D}} / t_{s_{A}}=10^{1.17188}=14.86 \approx 15 \\
& t_{s_{R}} / t_{s_{A}}=10^{1.36131} 22.98 \approx 23
\end{aligned}
$$

\begin{tabular}{|c|c|c|c|c|c|}
\hline Test Bars and Riser & $\mathbf{A}$ & $\mathbf{B}$ & $\mathbf{C}$ & D & Riser* \\
\hline Diameter or thickness of bar, $d(\mathrm{~mm})$ & 10 & 20 & 30 & 40 & $d=5 ; D=60$ \\
\hline Length of bar, $L(\mathrm{~mm})$ & 200 & 200 & 200 & 200 & $L=100$ \\
\hline$V=\frac{\pi d^{2} L}{4} \quad\left(m m^{3}\right)$ & 15708 & 62832 & 141372 & 251328 & 238237 \\
\hline$A=\frac{\pi d^{2}}{4}+\pi d L=\frac{\pi d^{2}+4 \pi d L}{4}\left(\mathrm{~mm}^{2}\right)$ & 6362 & 12881 & 19556 & 26389 & 20128 \\
\hline$V / A=\frac{d L}{d+4 L} \quad(m m)$ & 2.47 & 4.88 & 7.23 & 9.52 & 11.84 \\
\hline$d / L$ & 0.05 & 0.10 & 0.15 & $\mathbf{0 . 2 0}$ & 0.55 \\
\hline Relative solidification time $\left(t_{s_{i}} / t_{s_{n}}\right)$ & 1 & 4 & 9 & 15 & 23 \\
\hline $\begin{array}{l}\text { Remarks about the trend and direction of } \\
\text { cooling rate. }\end{array}$ & \multicolumn{5}{|c|}{$\begin{array}{l}\text { Increasing Cooling Rate } \\
\text { Decreasing Cooling Rate }\end{array}$} \\
\hline \multicolumn{6}{|c|}{$\begin{array}{l}\text { NB: } \boldsymbol{A} \text { excludes the common circular surface through which feeding and risering occurred. } \\
* \text { The riser is a conical frustum having top diameter bigger than bottom diameter. The } \\
d / L \text { for the riser was calculated using the average of the two diameters. The volume and area of top } \\
\text { circular surface plus slant surface are: } \\
\mathrm{V}_{\text {riser }}=\frac{\pi L}{3}\left(\frac{D^{2}}{4}+\frac{d^{2}}{4}+\frac{D d}{4}\right) ; \mathrm{A}_{\text {riser }}=\pi\left(\frac{D}{2}+\frac{d}{2}\right) \cdot\left(\left(\frac{D}{2}-\frac{d}{2}\right)^{2}+L^{2}\right)^{1 / 2}+\frac{\pi D^{2}}{4}\end{array}$} \\
\hline
\end{tabular}

Alternatively,

$$
\frac{t_{s_{B}}}{t_{s_{A}}}=\frac{B \cdot\left(\frac{V_{B}}{A_{B}}\right)^{n}}{B \cdot\left(\frac{V_{A}}{A_{A}}\right)^{n}}=\frac{\left(\frac{V_{B}}{A_{B}}\right)^{2}}{\left(\frac{V_{A}}{A_{A}}\right)^{2}}=\frac{(4.88)^{2}}{(2.47)^{2}}=\left(\frac{4.88}{2.47}\right)^{2}=(1.97571)^{2}=3.90 \approx 4 \text { (as in equation 14). }
$$

Similar analysis for $t_{s_{C}} / t_{s_{A}}, t_{s_{D}} / t_{s_{A}}$, and $t_{s_{R}} / t_{s_{A}}$ would produce 9,15 , and 23 respectively as in equations $15-17$. The values of $V, A, V / A, d / L$ and relative solidification times $\left(t_{s_{i}} / t_{s_{n}}\right)$ derived from the dimensions of the test bars and riser are shown in Table 2.

Table 2: Comparison of cooling rates based on casting modulus

Therefore, if the solidification time for test bar A $\left(t_{s_{A}}\right)$ is taken as 1 unit of time, then test bars $\mathrm{B}, \mathrm{C}$ and $\mathrm{D}$ will take 4, 9 and 15 times longer to solidify. This means that the cooling rate for bar A would be the fasted while that for bar D would be the slowest. Similarly, the riser will be the last component to solidify and will take 23 times longer than bar A. As summarized in Table 2, this means that the riser will retain liquid longer than all the test bars so that it could compensate for solidification shrinkage in the test bars. 
The mould was designed as shown in Figure 2 to achieve the solidification pattern anticipated. The riser is located nearest to the largest bar and furthest from the smallest one. The volume of test bars, riser and other parts of the gating system was used to calculate the weight of aluminium required. With loses and unavoidable accumulation in the crucible factored in, $4 \mathrm{~kg}$ (4000 g) of aluminium and $0.504 \mathrm{~kg}(504 \mathrm{~g})$ of silicon were charged. The $504 \mathrm{~g}$ of Si represents $12.6 \%$ by weight of the $4000 \mathrm{~g}$ of $\mathrm{Al}$, giving the eutectic composition.

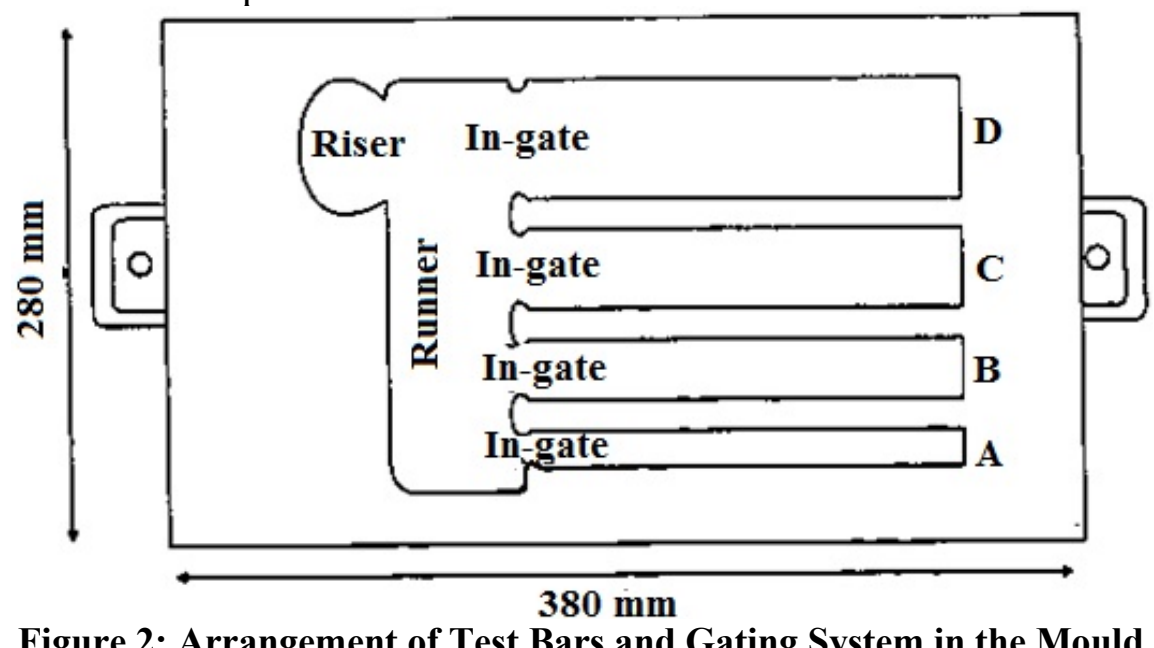

\subsection{Melting and Casting Procedure}

A laboratory tungsten-arc electric furnace was used for melting. The furnace, which can heat up to $1800^{\circ} \mathrm{C}$, has an attached digital pyrometer for temperature measurement. The steel crucible pot was preheated with the furnace before charging to drive off moisture and raise the thermal conditions of the pot. The aluminium ingot was cut into smaller pieces that could enter the pot and charged first. The temperature of the furnace was monitored from the readings displayed by the digital thermometer until the aluminium melted. At $700^{\circ} \mathrm{C}$, the crucible pot was brought out by means of a pair of tongs; and $504 \mathrm{~g}$ of silicon powder was introduced into the melt and stirred. The pot was put back and the furnace door closed. Heating was continued up to $1400^{\circ} \mathrm{C}$ to ensure complete melting and dissolution of the silicon granules in the molten aluminium. The furnace was turned off and the pot of molten alloy was then allowed to cool inside the furnace to avoid atmospheric attack on the melt. In between cooling, the furnace was put on at intervals to determine the temperature. This was continued down to $700^{\circ} \mathrm{C}$. It was brought out finally, and the melt was fluxed and degassed with $50 \mathrm{~g}$ of aluminium chloride by submerging it to the bottom of the melt.

The melt surface was skimmed. Pouring was done immediately into the mould until the metal filled the riser. The mould was left to cool overnight before shaking out.

\subsection{Spectrometric and Metallographic Examination}

Spectrometric analysis of the alloy was carried out using a sample collected from the solidified melt and machined into disc shape. Samples were also cut from the transverse section of each bar for microscopic examination using standard procedures [3]. Photomicrographs were taken at $200 \times$ magnification by means of a metallurgical microscope.

\subsection{Tensile and Hardness Tests}

A round or cylindrical tensile specimen was machined from the longitudinal section of each bar on the center lathe; each being proportional to the standard $12.5 \mathrm{~mm}$ diameter specimen with $62.5 \mathrm{~mm}$ gauge length in conformity with equation 18 [19].

$$
L_{o}=5.65 \sqrt{A_{o}} \cong 5 \mathrm{~d}_{o}
$$

Each specimen was tested in tension using a Monsanto tensiometer tensile testing kit. The crosshead moved at uniform rate of $10 \mathrm{~mm} /$ minute as each specimen was stretched, and the force on the specimen and corresponding extension were simultaneously measured until the specimen broke. 
The maximum force and the gauge length after fracture were noted. Two tensile specimens were produced and tested for each test bar, and the average value of strength and ductility were noted.

Circular specimens for Brinell hardness test were cut from the cross-section of each bar. They were machined to disc-like shape with the flat sides parallel and smooth. Two indentations were made on each sample using a ball indenter of $10 \mathrm{~mm}$ diameter and an applied load of $2.5 \mathrm{kN}$. The diameters of the indentations were measured by means of a microscope, and the average computed for each sample. The Brinell hardness number (HB value) for each sample was calculated using equation 19 [3].

$$
\mathrm{HB}=\frac{\text { Load in } \mathrm{kg}}{\text { Area of indentation in } \mathrm{mm}^{2}}=\frac{0.102 \mathrm{~F}}{0.5 \pi D\left[D-\sqrt{D^{2}-d^{2}}\right]}
$$

Where $\mathrm{D}=10 \mathrm{~mm}, \mathrm{~F}=2500 \mathrm{~N}$ and $\mathrm{d}$ varies with sample. The machine factor, $0.102=\frac{1}{g}=$ $\frac{1}{9.81}$ converts the load $\mathrm{F}$ from Newton $(\mathrm{N})$ to kilogramme $(\mathrm{kg})$.

\section{Results and Discussion}

\subsection{Spectrometric Analysis}

The spectrometric analysis of the alloy indicated the presence of ten elements: $\mathrm{Si}, \mathrm{Cu}, \mathrm{Mg}, \mathrm{Fe}$, $\mathrm{Mn}, \mathrm{Ni}, \mathrm{Zn}, \mathrm{Ti}, \mathrm{Cr}$, and $\mathrm{V}$, and of course, $\mathrm{Al}$ as shown in Table 3. The concentrations or percentage compositions of the constituents of alloy produced are compared with those of the Al-Si eutectic alloys LM6 and LM20, according to the BS 1490 [2] [3]. The alloy produced contains silicon up to the eutectic range, $10-13 \%$. Even though only $0.5 \mathrm{~kg}$ of $\mathrm{Si}$ was charged with $4 \mathrm{~kg}$ of $\mathrm{Al}$, (i.e. $\frac{0.5}{4} \times 100=12.5 \% \mathrm{Si}$ in $\mathrm{Al}$ ); the concentration indicated is $12.8 \%$, an increase of $0.3 \%$. This may be due to, either (i) the impurities already in the aluminium ingot whose purity was $98 \%$, or (ii) the conversion of some aluminium to dross during the melting process, thereby increasing the effective ratio of silicon to aluminium, or (iii) both. Since the alloy contains $85.3 \% \mathrm{Al}, 12.8 \% \mathrm{Si}, 1.0 \% \mathrm{Cu}$, and others $(0.47 \%)$; it may be specified approximately as $\mathrm{Al}-12.8 \mathrm{Si}-1.0 \mathrm{Cu}$ alloy.

Table 3: Composition of the alloy produced compared with alloys LM6 and LM20

\begin{tabular}{|c|c|c|c|c|c|c|c|c|c|c|c|c|c|}
\hline $\begin{array}{c}\text { Alloy } \\
\text { Designation }\end{array}$ & $\mathrm{Si}$ & $\mathrm{Cu}$ & $\mathrm{Mg}$ & $\mathrm{Fe}$ & $\mathrm{Mn}$ & $\mathrm{Ni}$ & $\mathrm{Zn}$ & $\mathrm{Pb}$ & $\mathrm{Sn}$ & $\mathrm{Ti}$ & $\mathrm{Cr}$ & $\mathrm{V}$ & $\mathrm{Al}$ \\
\hline LM6 & $10-13$ & 0.1 & 0.1 & 0.6 & 0.5 & 0.1 & 0.1 & 0.1 & 0.005 & 0.2 & - & - & $\begin{array}{c}85.15 \\
- \\
88.15\end{array}$ \\
\hline LM20 & $10-13$ & 0.4 & 0.2 & 1.0 & 0.5 & 0.1 & 0.2 & 0.1 & 0.1 & 0.2 & - & - & $\begin{array}{c}84.20 \\
- \\
87.20\end{array}$ \\
\hline $\begin{array}{c}\text { Alloy } \\
\text { Produced }\end{array}$ & 12.8 & 1.0 & 0.044 & 0.480 & 0.114 & 0.025 & 0.218 & - & - & 0.006 & 0.008 & 0.001 & 85.30 \\
\hline
\end{tabular}

\subsection{Mechanical Properties and Casting Section Size}

The trends in tensile strength, ductility and hardness of the cast test bars with respect to casting section size is summarized in Table 4. Each of the properties increased with decreasing section thickness. The relative solidification time (determined through design calculations in Table 2) also increased with casting section size as shown in Table 4 . The correlation between solidification time and section size is given by the $R^{2}$ value of 0.9796 in Figure 3. That is, solidification time depends on the section size up to $98 \%$. It implies that section size and solidification time will exert similar effects on the mechanical properties. 
Table 4: Strength, Ductility and Hardness of the Test Bars

\begin{tabular}{|c|c|c|c|c|c|c|}
\hline $\begin{array}{c}\text { Test } \\
\text { Bar }\end{array}$ & $\begin{array}{c}\text { Casting } \\
\text { Section } \\
\text { Size } \\
(\mathrm{mm})\end{array}$ & $\begin{array}{c}\text { Relative } \\
\text { Solidification } \\
\text { Time }\end{array}$ & $\begin{array}{c}\text { Tensile } \\
\text { Strength } \\
(\mathrm{MPa})\end{array}$ & $\begin{array}{c}\text { Ductility } \\
\text { (relative time units) }\end{array}$ & $\begin{array}{c}\text { Brinell } \\
\text { Hardness } \\
\text { Number } \\
(\mathrm{HB})\end{array}$ & $\begin{array}{c}\text { Strength } \\
\text { Ductility }\end{array}$ \\
\hline A & 10 & 1 & 130 & 8.2 & 45.4 & 15.854 \\
\hline B & 20 & 4 & 104 & 6.3 & 39.4 & 16.508 \\
\hline C & 30 & 9 & 83 & 5.2 & 36.5 & 15.962 \\
\hline D & 40 & 15 & 68 & 4.3 & 35.8 & 15.814 \\
\hline
\end{tabular}

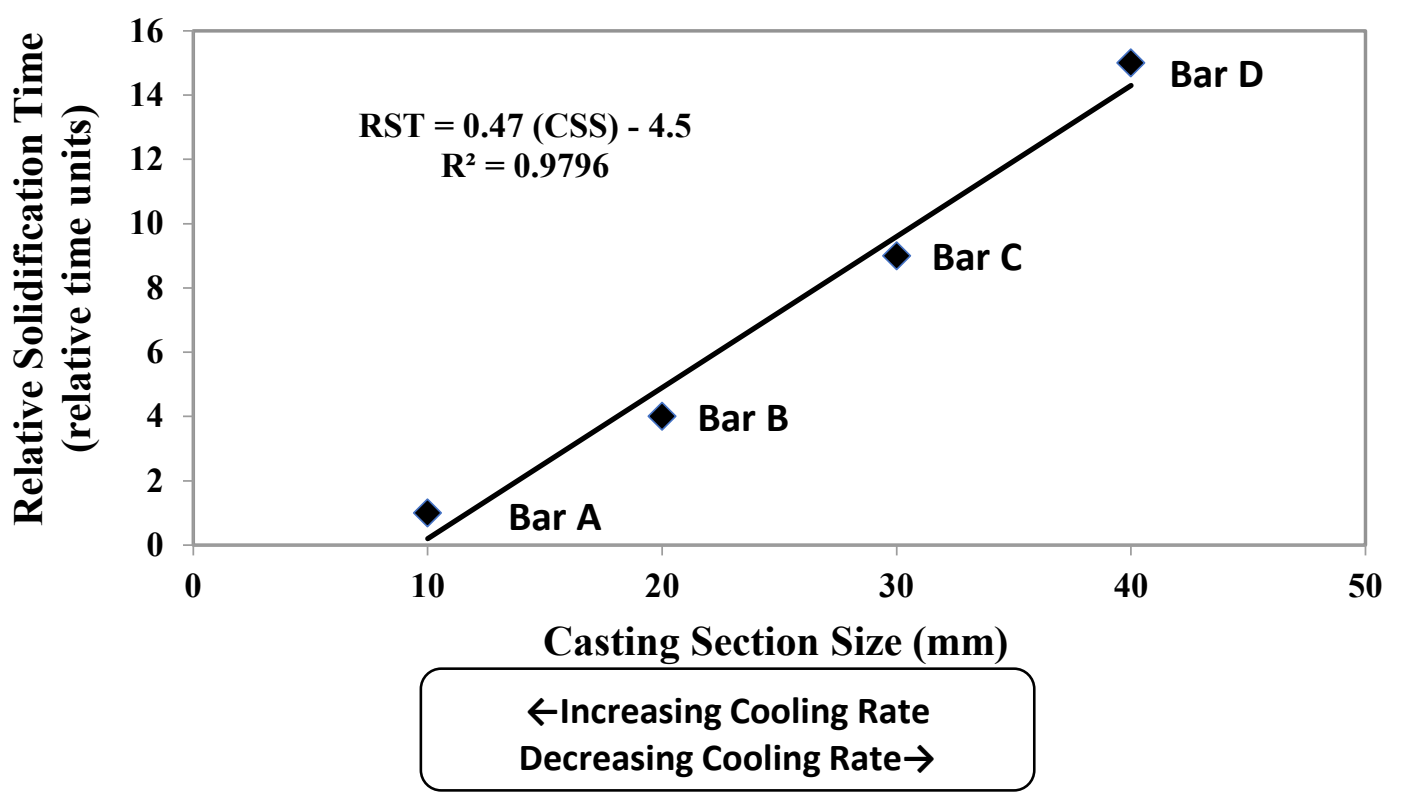

Figure 3: Effect of Casting Section Size on Solidification Time of AsCast Al-Si Eutectic Alloy

\subsubsection{Tensile Strength}

As illustrated in Figure 4, the tensile strength decreased with increasing section size, from bar A to D. That is, the highest value of strength was reported for bar A (section thickness, $10 \mathrm{~mm}$ ) while the lowest value occurred in the case of bar D (section thickness, $40 \mathrm{~mm}$ ). A similar trend was observed between tensile strength and solidification time (Figure 5). In both graphs (Figures 4 and 5), the curve sloped downwards as the casting section thickness increased or as the solidification time increased. This means that the cooling rate decreased as section size increased, leading to loss of strength in the cast bar. Therefore, thin sections should be used if maximum strength is required in aluminium casting alloys based on solidification treatment alone [1] [2]. The strength values of $130 \mathrm{MPa}$ (Bar A), $104 \mathrm{MPa}$ (Bar B), $83 \mathrm{MPa}$ (Bar C), and $68 \mathrm{MPa}$ (Bar D) all exceed the tensile strength reported for pure aluminium (55-60 MPa) [2] [3] [18]. This means that silicon increased the strength of aluminium at all cooling rates or section sizes. The relationship between tensile strength (TS) and casting section size (CSS) is a linear one $\left(\mathrm{R}^{2}=0.986\right)$, characterized by equation 20 .

$$
\mathrm{TS}=-2.07(\mathrm{CSS})+148
$$

Similarly, the relationship between tensile strength (TS) and relative solidification time (RST) is linear $\left(\mathrm{R}^{2}=0.9336\right)$ represented by equation 21 :

$$
\mathrm{TS}=-4.2417(\mathrm{RST})+127
$$




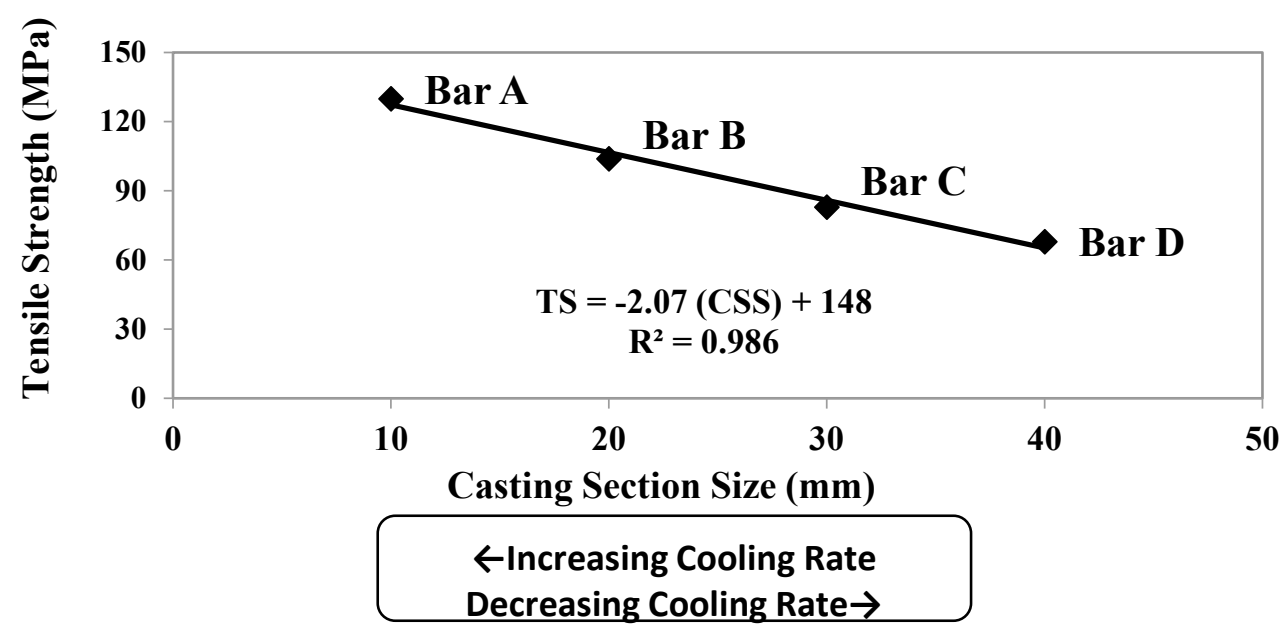

Figure 4: Effect of Casting Section Size on the Tensile Strength of As-Cast Al-Si Eutectic Alloy

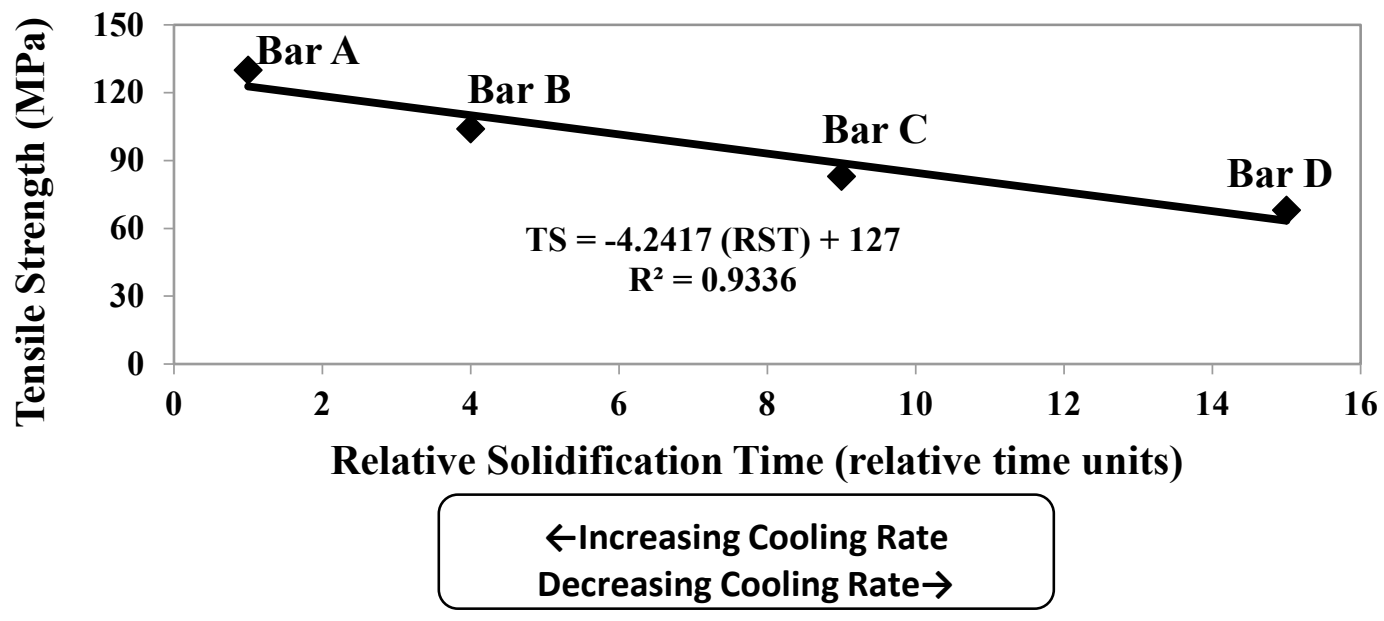

Figure 5: Effect of Solidification Time on the Tensile Strength of As-Cast Al-Si Eutectic Alloy

\subsubsection{Ductility (\% Elongation)}

The ductility expressed as percent elongation increased with decreasing section size (Figure 6), from bar D $(40 \mathrm{~mm})$ to bar A $(10 \mathrm{~mm})$. Ductility was also observed to decrease as solidification time decreased (Figure 7). Thus, the ductility decreased as section size increased, solidification time increased and cooling rate reduced. It means that strength and ductility both increased with decreasing section size. This is unusual. However, Al-Si eutectic and near-eutectic alloys are said to have anomalous structure [1] [2] [11]. Whereas slowly cooled Al-Si eutectic alloys exhibit low ductility because of the brittle nature of the large Si plates; rapid cooling is said to refine the microstructure making the Si phase assume a fibrous form with the result that both ductility and tensile strength are much improved [2] [14] [15] [20] [21] [22] [23] [24]. This explains why both strength and ductility were enhanced as casting section size thinned or as cooling rate increased. However, the elongation values of $8.2 \%$ (Bar A, $10 \mathrm{~mm}$ ), 6.3\% (Bar B, $20 \mathrm{~mm}$ ), 5.2\% (Bar C, $30 \mathrm{~mm})$, and 4.3\% (Bar D, $40 \mathrm{~mm}$ ) are far below ductility values of $30-60 \%$ reported for pure and annealed aluminium [2] [3] [18]. The presence of silicon lowered the ductility of aluminium, but refinement of microstructure by faster cooling rate brought about some improvement in the ductility. Similar observations about simultaneous increase in strength and ductility have been reported [25] [26] [27]. The linear relationship $\left(\mathrm{R}^{2}=0.9683\right)$ between ductility $(\% \mathrm{El}$.) and casting section size (CSS) is shown by equation 22. Similarly, equation 23 is a linear relationship $\left(\mathrm{R}^{2}=0.9\right)$ between ductility $(\% \mathrm{El}$.) and relative solidification time (RST).

$$
\% \mathrm{El} .=-0.128(\mathrm{CSS})+9.2
$$


$\% \mathrm{El} .=-0.2599(\mathrm{RST})+7.884$

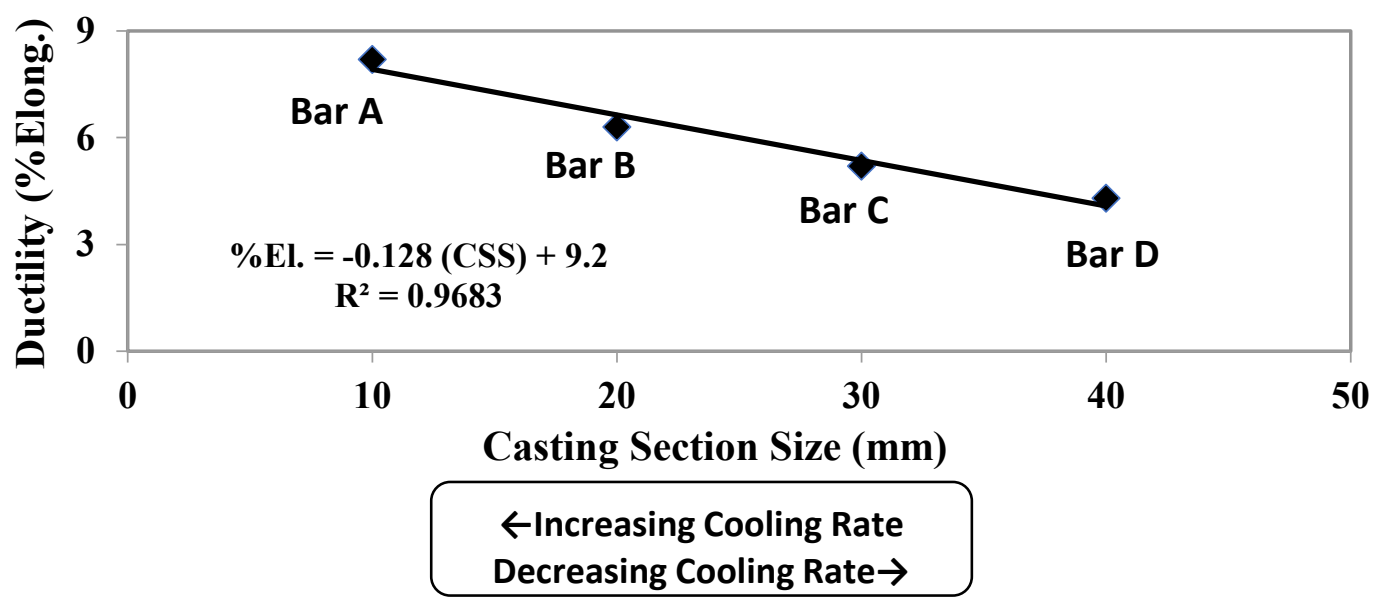

Figure 6: Effect of Casting Section Size on the Ductility of AsCast Al-Si Eutectic Alloy

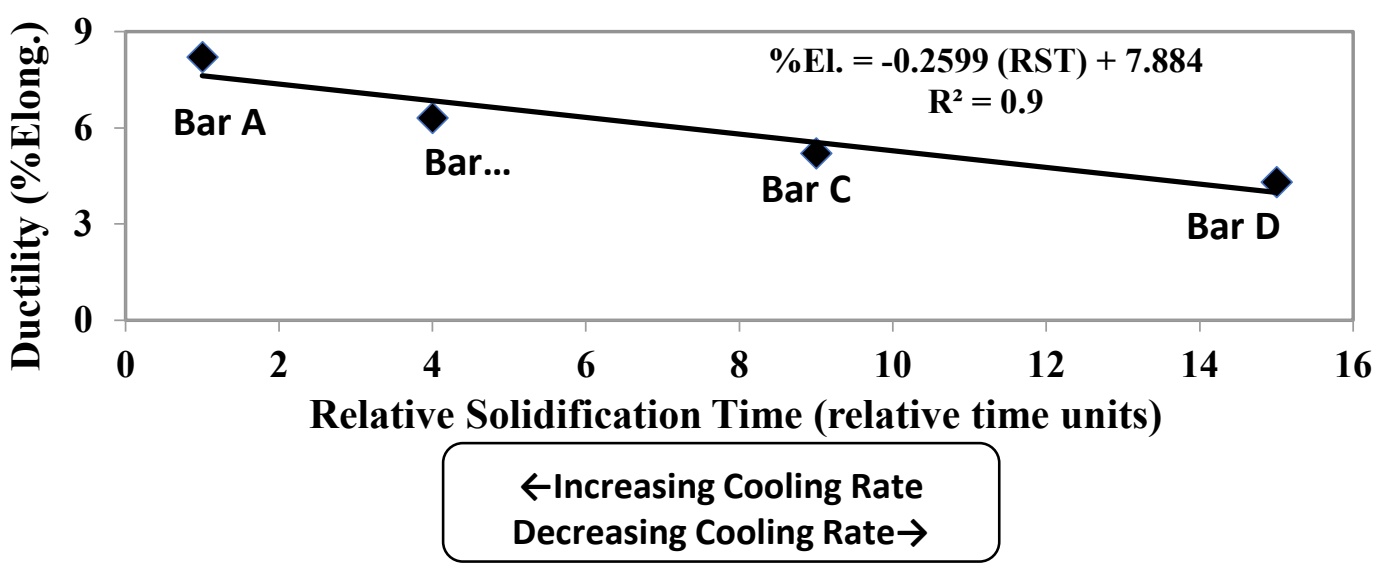

Figure 7: Effect of Solidification Time on the Ductility of AsCast Al-Si Eutectic Alloy

\subsubsection{Hardness (Brinell Scale)}

The Brinell hardness of the test bars decreased as the casting section size increased from bar A $(10 \mathrm{~mm})$ to bar D $(40 \mathrm{~mm})$, as shown in Figure 8. Similarly, Figure 9 shows that hardness decreased as solidification time increased or as cooling rate decreased. Thus, the diameter of indentation increased with increasing casting section size from bar A to bar D. Accordingly, the hardness value decreased as the casting section size increased from bar A to bar D because small indentation diameter tells how difficult it is to indent the specimen, and this difficulty decreased with decreasing casting section size i.e. increasing cooling rate. So, bar A has the highest hardness, and bar D the lowest. The hardness values of bar A $\left(45.4 \mathrm{~kg} / \mathrm{mm}^{2}\right)$, bar B $\left(39.4 \mathrm{~kg} / \mathrm{mm}^{2}\right)$, bar C $\left(36.5 \mathrm{~kg} / \mathrm{mm}^{2}\right)$, and bar $\mathrm{D}\left(35.8 \mathrm{~kg} / \mathrm{mm}^{2}\right)$ are all higher than the hardness of about $15 \mathrm{~kg} / \mathrm{mm}^{2}$ reported for pure aluminium [2] [3] [18]. Thus, silicon increased the hardness of aluminium, and rapid cooling (small section size) enhanced the hardness further.

The linear relationship $\left(\mathrm{R}^{2}=0.876\right)$ between Brinell hardness $(\mathrm{HB})$ and casting section size (CSS) is governed by the equation 24 , while that between hardness (HB) and relative solidification time (RST) is characterized by equation 25 with $\mathrm{R}^{2}=0.7687$.

$$
\begin{aligned}
& \mathrm{HB}=-0.317(\mathrm{CSS})+47.2 \\
& \mathrm{HB}=-0.6251(\mathrm{RST})+43.807
\end{aligned}
$$




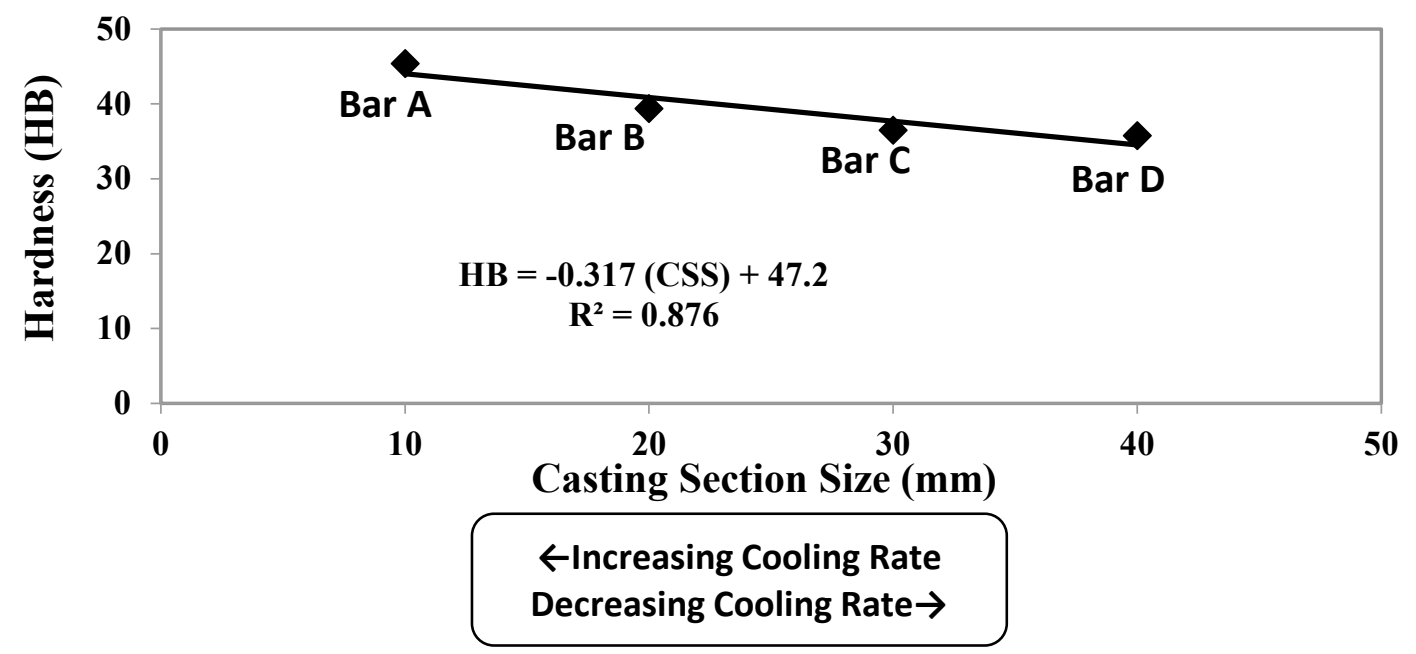

Figure 8: Effect of Casting Section Size on the Hardness of AsCast Al-Si Eutectic Alloy

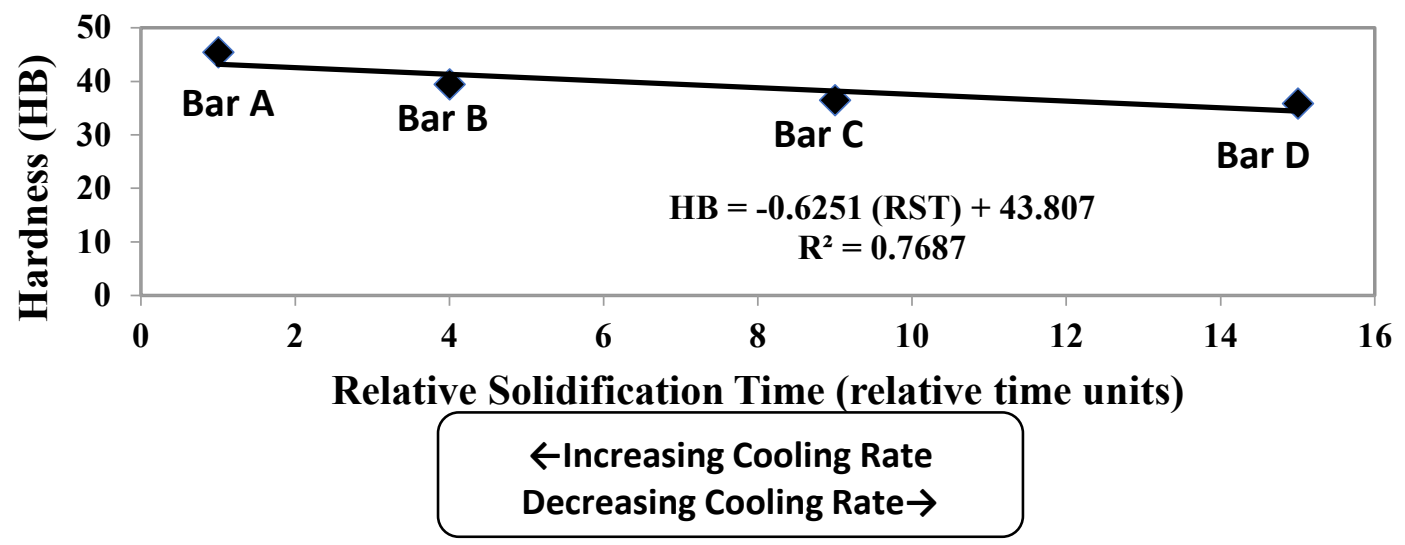

Figure 9: Effect of Solidification Time on the Hardness of AsCast Al-Si Eutectic Alloy

\subsubsection{Relationships Between Mechanical Properties}

The results in Table 4 show that the strength, ductility and hardness of the cast bars all increased as section size decreased or as cooling rate increased. The tensile properties (tensile strength and ductility) are particularly so well correlated [28] [29]. The ratio of strength to ductility approximates to a constant value of 16 . This means that the bars are as strong as they are ductile since the different section sizes or cooling rates increased the two tensile properties proportionally. The plot of tensile strength against ductility (\% elongation) in Figure 10 gives a straight line whose slope is 16.038 (i.e. ratio of strength to hardness) with $R^{2}$ of 0.9944 . The linear relationship between tensile strength (TS) and ductility (\%El.) is given by equation 26 .

$$
\text { TS }=16.038(\% \mathrm{El} .)
$$

The plot of Strength/Ductility ratio against casting section size is shown in Figure 11. The curve approximates to a straight line that is parallel to the abscissa with ordinate value of approximately 16. This confirms that strength and ductility increased or decreased in equal proportions as the section size or cooling rate increased or decreased. Equation 27 represents the relationship between strength/ductility ratio and casting section size (CSS). The intercept of 16.195 confirms that tensile strength to ductility ratio of the cast test bars tends towards 16 .

$$
\frac{\mathrm{TS}}{\% \mathrm{El} .}=-0.0066(\mathrm{CSS})+16.195
$$




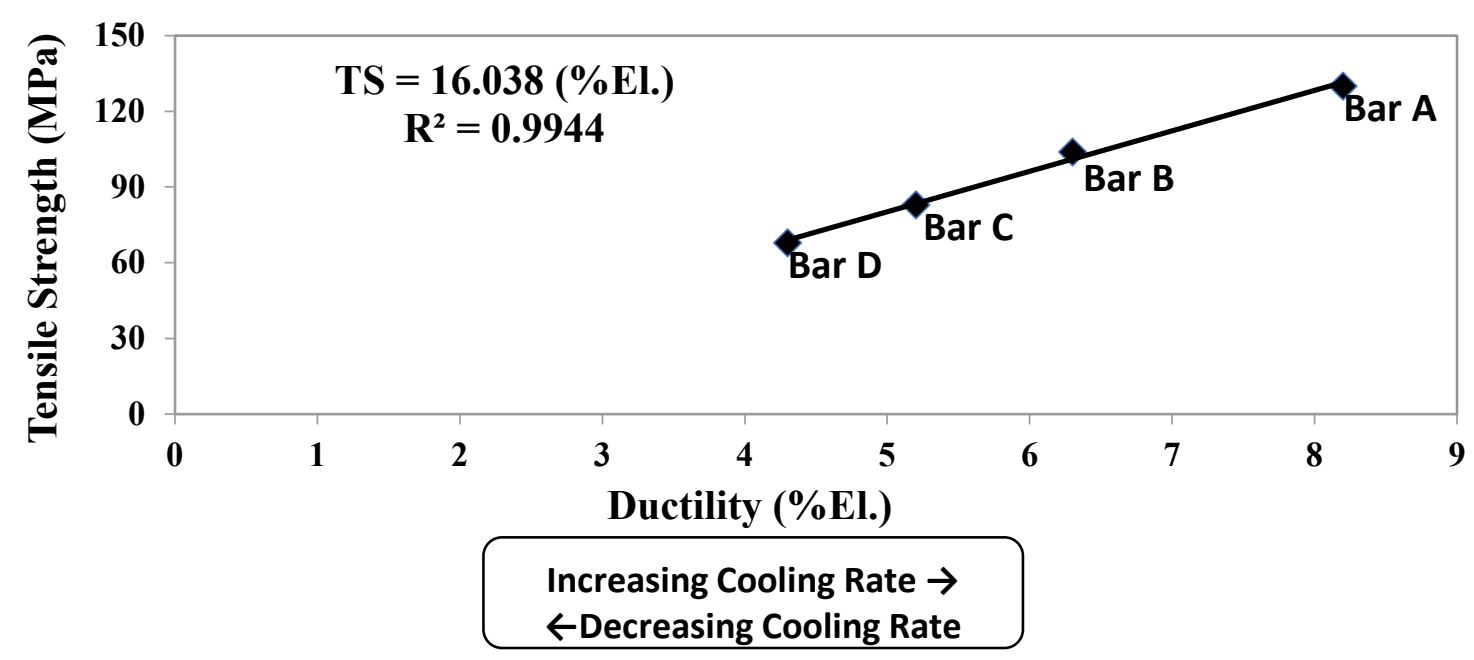

Figure 10: Correlation of Strength and Ductility for the Test Bars

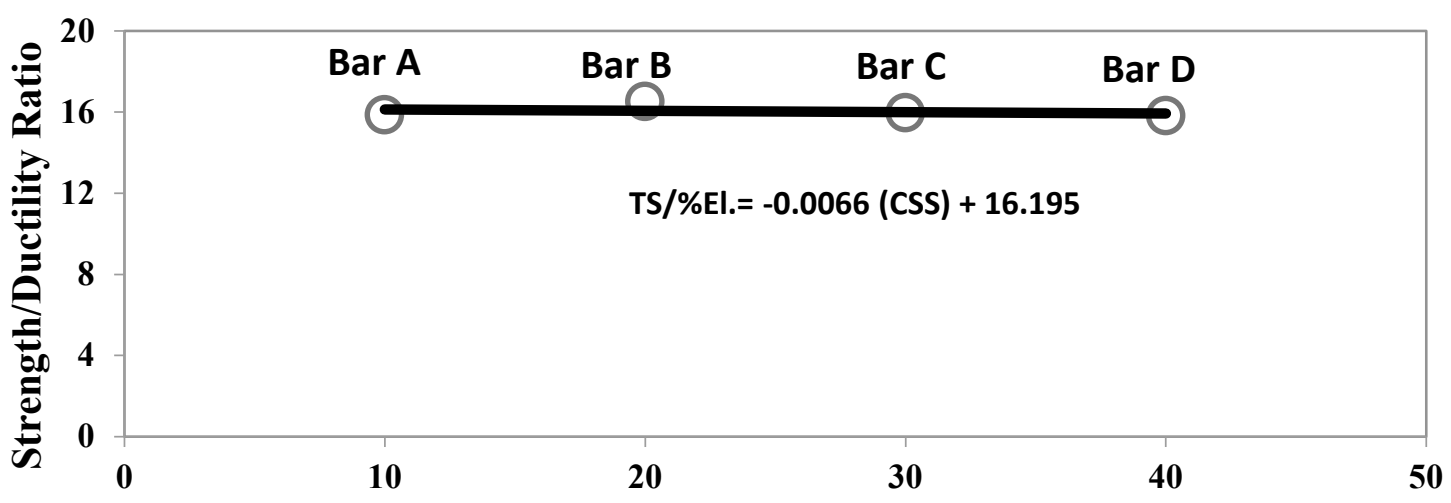

Corresponding Section Size of Cast Test Bars (mm)

$\leftarrow$ Increasing Cooling Rate

Decreasing Cooling Rate $\rightarrow$

Figure 11: Effect of Casting Section Size (Cooling Rate) on the Strength/Ductility Ratio of As-Cast Al-Si Eutectic Alloy

\subsection{Microstructure and Casting Section Size}

The photomicrographs taken from the transverse section of the bars are shown in Figure 12. It is difficult to discern the grain boundaries in the microstructures. This confirms the anomalous nature of Al-Si eutectic and near-eutectic alloys [2] [11]. However, all the microstructures show the silicon flake structure (dark regions) in the matrix of the aluminum phase, characteristics of unmodified eutectic solidification. The crystals or grains are not discernable, but the minor phase ( $\mathrm{Si}$ ) is dominantly visible in the microstructure [1] [11]. In Figure 12a (microstructure of bar A), the silicon flakes are finer, closely spaced and more evenly distributed within the Al matrix. This is because of the faster cooling rate in bar A, which has the smallest section size of $10 \mathrm{~mm}$. This structure is responsible for the superior mechanical properties of bar A. In the case of bar B (Figure 12b), the silicon flakes are coarser than those in Figure 12a and less evenly distributed within the aluminium matrix. This is due to the decrease in cooling rate of bar B (20 mm section size) compared to A. In Figure 12c (microstructure of bar $\mathrm{C}$ ), few flakes of silicon can be seen that are sparingly distributed within the aluminium matrix. The lower cooing rate of bar $\mathrm{C}$ (30 $\mathrm{mm}$ section size) compared to bars B (20 mm section size) and A (10 mm section size) is responsible for this structure. Hence, the mechanical properties of bar $\mathrm{C}$ are inferior to those of bars B and A accordingly. In Figure 12d (microstructure of bar D of $40 \mathrm{~mm}$ section size), the flakes are massive, coarse and clustered. The silicon grains are polyhedrally shaped, coarse, and scattered within the matrix of aluminium, resulting 
in decreased strength, hardness and ductility compared to bars A, B and C. The decreased cooling rate is instrumental. Clusters of free silicon particles are visible which constitutes stress concentration centers that weakened the material. This structure is characteristics of slow cooling which occurred in bar D, which has the largest section thickness of $40 \mathrm{~mm}$. Consequently, the lowest values of strength, hardness and ductility were recorded in the case of bar D.

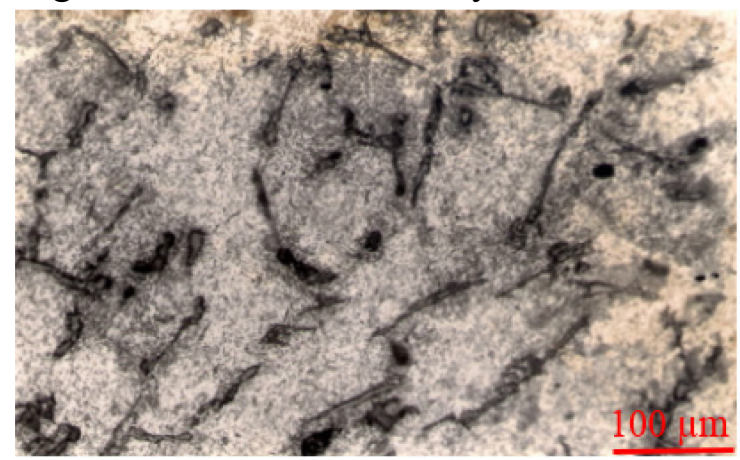

(a) Bar A

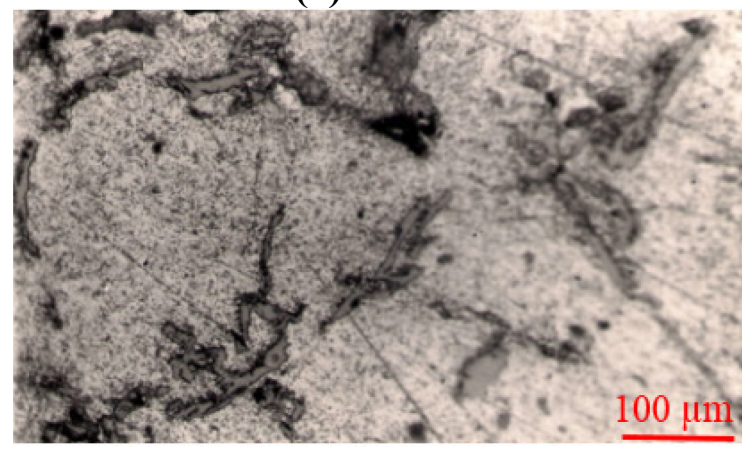

(c) Bar C

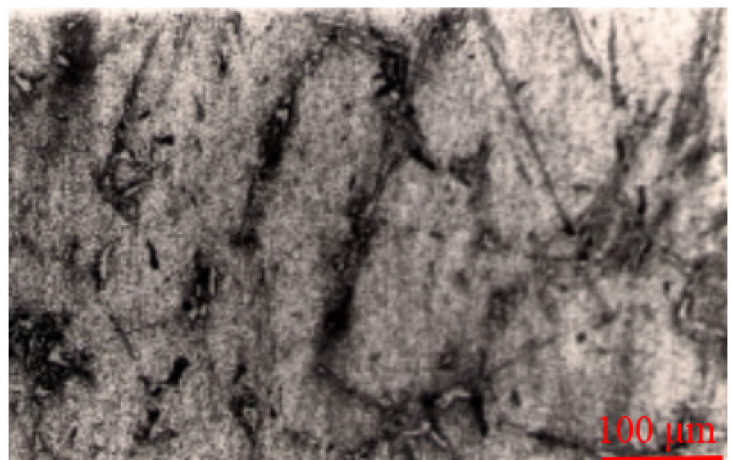

(b) Bar B

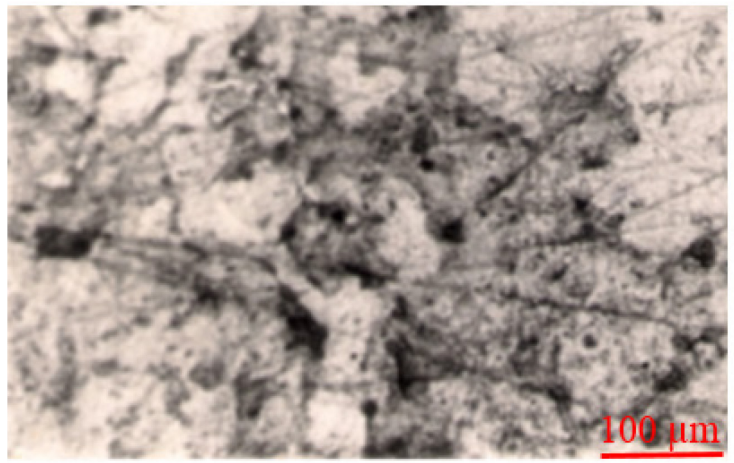

(d) Bar D

Figure 12: Photomicrographs Showing the Microstructures of the Four Test Bars $(200 \times)$

\section{Conclusion}

The processing condition (in this case, the rate of cooling or solidification) affects the structure, and by extension determines the properties of Al-Si eutectic alloys. The Al-Si alloy studied experienced higher cooling rate in thinner sections of the test bar, resulting in finer structures and hence better mechanical properties. The influence of section size (a determinant of cooling rate) is evident in the strength, ductility and hardness values obtained. For thin sections; strength, elongation (ductility) and hardness values are generally higher because of the faster rates of solidification and finer structures. The properties decreased as the thickness or section size increased. In general, the elongations were low (4.3-8.2\%), indicating that silicon lowers the ductility of aluminium. Pure aluminium elongates up to $60 \%$. However, the strength $(68-130 \mathrm{MPa})$ and hardness $(35.8-45.4 \mathrm{HB})$ improved because of the presence of silicon. The tensile strength and hardness of pure aluminium (annealed) are $55 \mathrm{MPa}$ and $15 \mathrm{HB}$ respectively.

The fine structure obtained in bars of thin section indicates that many cells nucleated due to greater under-cooling caused by larger surface area to volume ratio. The nucleated cells had little time to grow extensively due to fast solidification. The opposite is true for bars of large section size, where few cells nucleated and had more time to grow, resulting in coarse structure. It is concluded therefore that the mechanical properties of the Al-Si eutectic alloy are related to the structure, particularly the presence, size, shape and distribution of silicon particles and this is a function of the cooling rate. Even without special modification treatments, cooling rate alone can alter the solidification structure and properties of Al-Si alloys. However, the extent of rapid cooling achieved in the thinnest section in the sand mould was not enough to bring about a fully modified structure. Since a variety of solidification structures are possible in Al-Si alloys; this group of materials is open to the control and exploitation of any alloy developer, materials designer or manufacturer to elicit the 
desired structures (and hence properties) for different applications. It is recommended that cooling rate should be investigated by direct temperature-time measurement using solidification analogue equipment.

\section{Conflict of Interest}

The author hereby declares that there is no conflict of interest whatsoever with the publication of this work

\section{Acknowledgments}

The author is grateful to the Projects Development Institute (PRODA), Enugu; Standards Organization of Nigeria (SON), Enugu; First Aluminum (Nig.) Plc, Port-Harcourt and Federal University of Technology Owerri (FUTO) for providing space and facilities. The late Engr. Prof. O.E. Okorafor of MME Dept., FUTO is acknowledged posthumously for his interest in this work.

\section{References}

[1] Polmear, I.J., StJohn, D., Nie, J.F. \& Qian, M. (2017): Light Alloys: Metallurgy of the Light Metals, (Fifth ed.). Oxford: Butter-Worth Heinemann. pp. 108-131.

[2] Elliott, R. (1997): Eutectic Solidification Processing; Crystalline and Glassy Alloys. Oxford: Butterworths Monographs in Materials.

[3] Higgins, R.A. \& Bolton, W. (2015). Materials for Engineers and Technicians, (Sixth ed.); Oxford: Routledge, pp.31, 32, 57-67, 127-138, 235-249.

[4] Asensio-Lozano, J \&.Voort, G.V. (2015). The Al-Si Phase Diagram. Tech-Notes, Volume 5, Issue 1, pp. 1-5, Published by Buehler, A Division of Illinois Tool Works Inc.

[5] Robles-Hernandez, F.C., Ramírez, J.M.H. \& Mackay, R. (2017). Al-Si Alloys: Automotive, Aeronautical, and Aerospace Applications. Cham, Switzerland: Springer International Publishing AG. https://dx.doi.org/10.1007/978-3-319-58380-8

[6] Okorafor, O.E. (2004): Expendable Polystrene Pattern Cast Process: A Revolution in Foundry Technology, Inaugural Lecture Series 7 of FUTO, Owerri: FUTO Press. pp. 80

[7] Onyemaobi, O.O. (2002): Mineral Resources Exploitation, Processing and Utilization - A Sine Qua Non for Nigeria's Metallurgical Industrial Development, Inaugural Lecture Series 5 of FUTO, Owerri: FUTO Press. pp.48

[8] Cottrell, A.H. (1995): An Introduction to Metallurgy, (Second ed.). London: The Institute of Metals, pp.177-189.

[9] Reif W. \& Muller K. (1998). Improvement of Mechanical Properties of Al-Si-Cast Alloys by Grain Refinement and Modification. In R. Ciach (ed.), Advanced Light Alloys and Composites Berlin: Kluwer Academic Publishers., pp. 263-275. https://dx.doi.org/10.1007/978-94-015-9068-6

[10] Abbaschian, G.R. Abbaschian, L. \& Reed-hill, R.E. (2009): Physical Metallurgy Principles, (Fourth ed.). Connecticut: Cengage Learning, pp.437-445.

[11] Porter, D.A., Easterling, K.E. \& Sherif, M.Y. (2009). Phase Transformations in Metals and Alloys, (Third ed.), Florida: Taylor \& Francis Group, pp.220-227.

[12] Liu, N., Kang, G. \& Liu, Z. (2012). Effect of Compound Modification on Microstructure and Properties of High Silicon Aluminum Alloy. Advanced Materials Research Vols. 476-478 pp 114-117. https://dx.doi.org/10.4028/www.scientific.net/AMR.476-478.114

[13] Dang. B., Zhang, X., Chen, Y.Z., Chen, C.X., Wang, H.T. \& Liu, F. (2016). Breaking through the strength-ductility trade-off dilemma in an Al-Si-based casting alloy. Nature Scientific Reports, 6:30874, pp.1-10. https://dx.doi.org/10.1038/srep30874 
[14] Zhang, L.Y., Jiang, Y.H., Ma, Z., Shan, S.F., Jia, Y.Z., Fan, C.Z. \& Wang, W.K. (2008). Effect of cooling rate on solidified microstructure and mechanical properties of aluminium-A356 alloy, Journal of Materials Processing Technology, 207: 107-111. https://dx.doi.org/10.1016/j.jmatprotec.2007.12.059

[15] Zhuo, L., Pang, S., Wang, H. \& Zhang, T. (2010). Effect of cooling rate on microstructure and mechanical properties of rapidly solidified Al-based bulk alloys. Journal of Alloys and Compounds, 504S: S117-S122. https://dx.doi.org/10.1016/j.jallcom.2010.03.211

[16] Guzel, E., Yuksel, C., Bayrak, Y., Sen, O. \& Ekerim, A. (2014). Effect of Section Thickness on the Microstructure and Hardness of Ductile Cast Iron. Metallography and Hardness Measurements, 56(4): 285-288. https://dx.doi.org/10.3139/120.110558

[17] Sahu, S., Bhat, M.N., Kumar, A., Pratik, A. \& Kumar, A. (2014). Effect of Section Thickness on the Microstructure and Hardness of Gray Cast Iron (A Simulation Study). International Journal of Engineering Research \& Technology, 3(7): 35-40

[18] Askeland, D.R. \& Wright, W.J. (2016). The Science and Engineering of Materials, (Seventh ed.); Connecticut: Cengage Learning, pp.305-330.

[19] ASTM International (2016). Standard Test Methods for Tension Testing of Metallic Materials: ASTM/E8E8M.37691. https://dx.doi.org/10.1520/E0008_E0008M-16A

[20] Shabestari, S.G. \& Malekan, M. (2005). Thermal analysis study of the effect of the cooling rate on the microstructure and solidification parameters of 319 aluminum alloy. $\begin{array}{lllll}\text { Canadian } & \text { Metallurgical } & \text { Quarterly, } & 44 & \text { 305-312. }\end{array}$ https://dx.doi.org/10.1179/cmq.2005.44.3.305

[21] Singh, R.K. Telang, A. \& Das, S. (2016). Microstructure and Mechanical Properties of Al-Si Alloy in As-cast and Heat-Treated Condition. American Journal of Engineering Research, 5(3):133-137

[22] Suareza, M.A., Figueroab,I., Cruza, A. Hernandeza, A. \& Chavez, J.F. (2012). Study of the AlSi-X System by Different Cooling Rates and Heat Treatment. Materials Research. 15(5): $763-$ 769. https://dx.doi.org/10.1590/S1516-14392012005000103

[23] Thompson, S., Cockcroft, S.L. \& Wells, M.A. (2004). Effect of cooling rate on solidification characteristics of aluminium alloy AA 5182. Materials Science and Technology, 20: 497-504. https://dx.doi.org/10.1179/026708304225012053

[24] Tian, L., Guo, Y., Li, J., Xia, F., Liang, M. \& Bai, Y. (2018). Effects of Solidification Cooling Rate on the Microstructure and Mechanical Properties of a Cast Al-Si-Cu-Mg-Ni Piston Alloy. MDPI Materials, 11, 1230; pp.2-9. https://dx.doi.org/10.3390/ma11071230

[25] Han, S.Z., Choi, E., Park, H.W., Lim, S.H., Lee, J., Ahn, J.H., Hwang, N-M. \& Kim, K. (2017). Simultaneous increase in strength and ductility by decreasing interface energy between Zn and Al phases in cast Al-Zn-Cu alloy. Nature Scientific Reports, 7: 12195, pp.1-8. https://dx.doi.org/10.1038/s41598-017-12286-7

[26] Rao, P.N., Kaurwar, A. Singha, D. \& Jayaganthana, R. (2014). Enhancement in Strength and Ductility of Al-Mg-Si alloy by Cryo-rolling followed by Warm rolling. Procedia Engineering, 75 :123-128. https://dx.doi.org/10.1016/j.proeng.2013.11.027

[27] Liu, F.C., Yang, Z.N., Zheng C.L. \& Zhang, F.C. (2011). Simultaneously improving the strength and ductility of coarse-grained Hadfield steel with increasing strain rate. Scripta Materiala, 66: 431-434. https://dx.doi.org/10.1016/j.scriptamat.2011.12.005

[28] Anilchandra, A.R., Arnberg, L., Bonollo, F., Fiorese, E. \& Timelli, G. (2017). Evaluating the Tensile Properties of Aluminum Foundry Alloys through Reference Castings-A Review. MDPI Materials,10, 1011; pp.1-12. https://dx.doi.org/10.3390/ma10091011

[29] Caceres, C.H., Svensson, L. \& Taylor, J.A. (2003). Strength-Ductility Behaviour of Al-Si-CuMg Casting Alloys in T6 Temper. International Journal of Cast Metals Research, 15:531-543. https://dx.doi.org/10.1080/13640461.2003.11819539 